\title{
THE STUDY OF EFFECTIVENESS OF THE MANAGEMENT OF ENTERPRISE IN THE ASPECT OF OPTIMIZATION OF TAXATION ON EXAMPLE OF AMORTIZATION POLICY
}

\author{
Alla Grinko \\ Department of Accounting, Auditing and Taxation \\ Kharkiv State University of Food Technology and Trade \\ 333 Klochkivska str., Kharkiv, Ukraine, 61051 \\ grinko.alla@gmail.com \\ Irina Voloshenyuk \\ Department of Accounting, Auditing and Taxation \\ Kharkiv State University of Food Technology and Trade \\ 333 Klochkivska str., Kharkiv, Ukraine, 61051 \\ vira2208@yandex.ua
}

\begin{abstract}
The questions of tax planning as the one of conditions of effective development of native enterprises were studied. Despite the fact that in theory the taxes must not manage the whole activity of enterprise and essentially change the philosophy of business, on practice taxes are the powerful instrument of economic regulation, completely influence the degree of strategic decisions, compel leaders to change the tactics of enterprises actions cardinally. The analysis of the influence of accounting policy on tax commitments allows make a conclusion that the methods of costs accounting, methods of amortization charging, variants of valuation of assets and debts, possibility of creation of the reserve funds influence the reflection of the results of enterprise activity in financial reporting and, correspondingly, the value of taxation base. That is why their correct choice would help to the leaders of enterprise to choose the necessary levers of tax planning for optimization of taxation. The elements of accounting policy that influence or can influence the tax commitments on the example of accounting of the fixed assets are considered. The algorithm of calculation of economic effect in the result of the use of mechanism of accelerated amortization of the active part of fixed assets on the base of given value of money was offered and the influence of the part of surplus value on the choice of tax system was analyzed on the example of formation of enterprise amortization policy. The elaborated algorithm of tax optimization allows mobilize the additional investment resources of economic subject and decrease the tax load. The offered calculation of the value of economic effect relative to the cost of each group by operation life has a great practical importance, because it demonstrates the sum of profit, lost at the end of service term of each group depending on operation life.
\end{abstract}

Keywords: tax planning, accounting policy, valuation, strategy, management, amortization, accounting information, tax optimization, taxes.

\section{Introduction}

The one of main aims of economic policy of any enterprise is minimization of expenditures, including the ones, connected with tax payment - both the direct sums of taxes and indirect expenditures (documentation, completion and presentation of declarations and so on). In the aspect of taxation the whole process of economic subjects' activity is mediated by appearance and change of tax relations. It is necessary to prognosticate the appearance of such relations and also tax bases, tax expenditures before realization of correspondent operations. The tax planning reduces the uncertainty of future tax expenditures of economic subjects and degree of their adaptation to the external environment. The efficiency of tax planning is valuated taking into account the level of tax load on enterprise.

The importance of current (internal) reserves abruptly grows under conditions of general financial-economic crisis, because there appears a possibility to raise the final financial results of enterprise activity without involvement of additional financing sources. The process of bringing the tax situation of economic subject to the most optimal state in the aspect of tax load received the name tax optimization. The instruments and algorithms of optimization of tax calculation must be 
adequate to the current condition of the state tax system. That is why scientific studies, devoted to the problems of improvement of tax planning, always have the specific topicality.

\section{Analysis of literary sources and statement of problem}

For today the direction, named the theory of tax planning, is formed within the tax theory. Many works of representatives of the different schools and directions of economic theory were devoted to the study of tax influence on entrepreneurial activity. In scientific works of the authors [1-4] the essence of taxes is considered as merely economic category. Thus, A. Smith stated that the tax it is a fair price for state services. A. Smith wrote: "The government expenditures for its lieges it is the same that the expenditures of administration relative to the masters of large estate, who must take part in these expenditures, in correspondence with the volume of income, received by each person from this estate" [1, p. 78]. The most important contribution of A. Smith in the science about taxes is in fact that he formulated the main principles of taxation clearly. The non-economic (social, political, mental, ethical) nature of taxation can be most adequately explained from the position of institutionalism theory [5-7]. The Swiss economist G. Sismondi developed the point of view about the unproductive character of state expenditures but objected the taxation of capital, because "it can lead to the reduction of state incomes in future" [8], and I. Ozerov wrote on this problem: "To tax a capital means to annihilate it - it is like to kill chicken that lays the golden eggs" [9]. As far as tax planning must correspond to the defined criteria, that allow distinguish it from the tax evasion, it must be based only on the variance of existent legislation. The modern economist Y. Ivanov indicates that "to reduce the absolute value of tax expenditures without violation the norms of existent legislation it is an absolutely real task" [10].

The problems of establishing of entrepreneurship in Ukrainian transformational economy, especially their tax aspect are considered in the works of modern Ukrainian economists [10-14]. In the native special literature the tax planning is most often considered as a component of financial-economic activity, which task is maximization of incomes by minimization of taxes. "Tax planning must become the necessary instrument in the managerial set of Ukrainian entrepreneurship at accepting one or another managerial decision" [11]. According to the definition of S. Suprunenko: "tax planning it is an instrument of building of the optimal business parameters, based on legislatively set ways of taxation that favors the raise of investment attractiveness of enterprise" [12].

The most universal is the definition of tax planning as "integration process of rationalization of economic activity from the position of correspondence to the existent tax legislation and the strategy of viability of economic subjects" [13].

Thus, the development of theory allowed define the nature and significance of economic planning; elaborate the principles of organization of tax planning, its components and ways of realization; elaborate technology of tax planning, consisted of several interconnected stages. At the same time, as the result of reformation of accounting system using international standards there appears the necessity of the further deep study of these questions.

\section{Aims and methods of research}

Based on topicality of the problem, it was determined, that the aim of research is the analysis of influence of taxation on entrepreneurial activity and also elaboration of the ways of optimization of tax effect on the development of entrepreneurial resource on the example of amortization policy of enterprise.

The following tasks were solved for attaining the set aim:

1. To reveal the features of taxation in the system of free entrepreneurial activity.

2. To determine the interconnection between tax planning and accounting policy of enterprise.

3. To offer the algorithm of calculation of economic effect in the result of the use of mechanism of accelerated amortization of the active part of fixed assets on the base of the value of money.

\section{Materials and methods of research}

Theoretical grounding is based on observations, grouping, analytic work at determination of the problems and tendencies of enterprise development at the expense of optimization of taxation, 
formation of accounting and tax policy at enterprises, generalization of the results and elaboration of recommendations for organization of tax planning. Theoretical foundation of research was methodological and general scientific principles of complex studies.

\section{Results of researches}

For today the series of economic and socio-legal factors conditions the increased importance of tax planning as a condition of effective development of native enterprises. It is connected with the fact that tax optimization is a current reserve of increase of financial results of enterprises activity, characterized with relatively short period of realization and prompt effect. As it is well-known, tax planning must be based on the variance of accounting procedures that are not in conflict with existent tax legislation. We agree with the idea of A. Zavgorodny and A. Eliseev that "Optimization of taxation in most universal understanding is defined as the comparison of the different variants of business activity and the use of resources for revelation of the lowest level of tax commitments, appeared at that" [14].

At consideration of the influence of accounting policy on the volume of tax commitments it is necessary to take into account the fact that in most cases this influence is in tax credit, because the influence of accounting policy on, for example, the profits tax is usually leveled on the long time interval. Thus, at consideration of questions, connected with the decrease of tax volume at the expense of using the mechanism of accelerated amortization it is obvious, that the sum of wear and tear of the fixed assets for the whole period of functioning of concrete object will be the same, despite the chosen variant of the wear and tear charging. In this situation we can talk only about the tax credit. In this connection we do not support the idea of several authors, who calculate the economic effect of the chosen variant of accounting by the direct method. Thus, for example, the article of M. Semenova "The influence of accounting policy on tax commitments of organization" [15] demonstrates that the tax economy ( $\mathrm{Sa}$ ) from the volume of amortization deductions (A) at the expense of using the accelerated amortization of the fixed assets can be calculated by the following formula 1 :

$$
\mathrm{Sa}=\mathrm{rpr} \times \mathrm{A}+\mathrm{rim} \times \mathrm{A} / 2-\mathrm{rp} \times \mathrm{rim} \times \mathrm{A} / 2,
$$

where rpr - rate of profit tax; rim - rate of property tax.

From our point of view, this formula can not be used for estimation of the influence of accounting policy on tax commitments because it has sense only for calculation of the tax economy on determined time interval. It does not take into account the possible losses in following periods, when the charge of wear and tear of the completely amortized fixed assets would be stopped, but the objects of the fixed assets continue to function. At the expense of it, the decrease of cost price relative to the method of even charging of wear and tear must take place in these periods. Because of the same cause this formula can deceive the analyst, who works with it, because at calculation of tax economy, for example, from debiting of $50 \%$ of cost of the fixed productive assets as amortization deductions by the small enterprises, the sum of charged wear and tear significantly grows, in which connection there can be made a conclusion about the absolute tax advantages of this method for all reporting periods.

From our point of view, the complex influence of accounting policy on tax commitments can be considered exclusively on the base of principle of time value of money. This principle is widely used in Western theory and practice at the solution of the series of questions of accounting, such as leasing agreements, credit and debtor indebtedness, operations with bonds and other papers, planning of involved capital and determination of its sources, valuation and revaluation of assets and many other.

We support the idea of V. V. Titov that "The general income is determined by the sum of discounted volume of pure money flow; just the pure money flow is a base of valuation of effectiveness of enterprise activity" [16]. So, the future value of the sum of assets, present for the current moment, in a year would be equal to the current nominal value plus the profit on it, expressed in percents. 
Let's consider the elements of accounting policy that influence or can potentially influence the tax commitments on the example of account of fixed assets. Today the linear method and the method of accelerated amortization of the active part of the fixed productive assets do not conflict with tax legislation relative to the order of wear and tear (amortization) charging of the fixed assets. The second method is preferential because of more fast transfer of value on the cost price of product (works, services) and getting of profit tax credit. Relative to the other methods of wear and tear charging of the fixed assets, allowed for today only for the aims of accounting, it is necessary to note, that two of them - the method of debiting of value by the sum of the numbers of years of the beneficial use term and the method of decreased balance that is in fact the accelerated amortization. If the possibility to accept amortization, calculated according to $\mathrm{P}(\mathrm{S}) \mathrm{A} 7$, for the tax aims would be established by law, the leaders of enterprise can analyze the possibility of using methods of optimization of tax expenditures, contained in it.

Thus, the use of accelerated amortization is an important factor of tax planning for enterprises that have the significant specific gravity of the fixed assets in the general value of property. In this connection the algorithm of calculation of economic effect in the result of the use of mechanism of accelerated amortization of the active part of fixed productive assets on the base of the value of money is offered. Let's introduce the conventional signs:

$-\mathrm{T}-$ duration of the fixed asset operation $(\mathrm{N}+\mathrm{D})$;

$-\mathrm{N}$ - number of years of the use of accelerated amortization;

$-\mathrm{D}$ - number of years of the work of fixed asset without amortization charging on it;

$-\mathrm{K}-$ acceleration coefficient. Its values are in interval from 1 to 2 ;

$-\mathrm{R}$ - increase of value of amortization deductions as the result of the use of accelerated amortization mechanism on the time interval $\mathrm{N}$;

$-(-Q)$ - decrease of the value of amortization deductions as the result of the use of accelerated amortization mechanism on the time interval $\mathrm{D}$;

$-\mathrm{C}-$ initial cost of the fixed assets;

$-\mathrm{i}$ - rate of income from investment of the temporarily free sums of taxes in production.

Let's present the differences between accelerated amortization and amortization, charged by the linear method graphically (Fig. 1):

\begin{tabular}{|c|c|c|c|c|c|c|c|c|c|}
1 & 2 & 3 & $\cdots$ & $\mathrm{N}-1$ & $\mathrm{~N}$ & $\mathrm{~N}+1$ & $\mathrm{~N}+2$ & $\cdots$ & $\mathrm{T}$ \\
year & year & year & & year & year & year & year & & year \\
\hline $\mathrm{R}$ & $\mathrm{R}$ & $\mathrm{R}$ & $\mathrm{R}$ & $\mathrm{R}$ & $\mathrm{R}$ & $-\mathrm{Q}$ & $-\mathrm{Q}$ & $-\mathrm{Q}$ & $-\mathrm{Q}$ \\
$\underset{5}{\longrightarrow}$ & T years \\
$\underset{5}{\longrightarrow}$
\end{tabular}

Fig. 1. The differences between accelerated amortization of fixed assets and amortization, charged by the linear method

We can see on the graph that operating life of the fixed asset $\mathrm{T}$ consists of two time intervals: $\mathrm{N}$ - at which the overrating of the sums of charged wear and tear (amortization) relative to the linear method of repayment the cost of fixed assets takes place and D - at which the charging of amortization is stopped as the result of full transfer of the object cost on cost price of production (works, services). The operating time of the fixed asset $-\mathrm{T}$ value - is determined according to the set norms of amortization deductions for the complete renewal of the fixed assets. The values $\mathrm{N}$ and $\mathrm{D}$ are found depending on $\mathrm{T}$ and acceleration coefficient $\mathrm{K}$ and are calculated by the formulas 2 and 3, respectively:

$$
\begin{gathered}
\mathrm{N}=\mathrm{T} / \mathrm{k}, \\
\mathrm{D}=\mathrm{T}-\mathrm{N}=\mathrm{N}-\mathrm{T} / \mathrm{k}=\mathrm{N}(\mathrm{k}-1) / \mathrm{k} .
\end{gathered}
$$


Values $\mathrm{R}$ and $\mathrm{Q}$ are calculated by the formulas 4 and 5:

$$
\begin{gathered}
\mathrm{R}=\mathrm{C}(\mathrm{k}-1) / \mathrm{T}, \\
\mathrm{Q}=\mathrm{R} /(\mathrm{k}-1) .
\end{gathered}
$$

From our point of view, the rate of income 1 can be calculated as following (6):

$$
\mathrm{i}=\mathrm{r}(1-0,18) \text {, }
$$

where $\mathrm{r}$ - profitability of the whole capital, determined by the formula 7 :

$$
\mathrm{r}=\frac{\text { balance profit }}{\text { sum of balance }- \text { net }} \text {. }
$$

The calculation of value 1 on the base of profitability of the whole capital of enterprise is logic, because the temporarily free facilities can form any item of balance asset. If the increase or decrease of profitability of the capital is planned, it is expedient to accept the planned value of this parameter for the calculation of economic effect from the tax credit. The correction of value $r$ on multiplier (1-0.18) is aimed at the exclusion of the profit tax influence $(18 \%)$.

Thus, the offered algorithm of calculation of economic effect from the use of accelerated amortization at formation of accounting policy at enterprise would help its leaders to choose the necessary levers of tax planning. The increase of enterprise assets value before the end of the last year of the fixed asset $\mathrm{T}$ operation for each of $\mathrm{N}$ years is correspondingly (8):

$$
0,18 \times \mathrm{R}(1+\mathrm{i})^{\mathrm{T}-1} ; 0,18 \times \mathrm{R}(1+\mathrm{i})^{\mathrm{T}-2}: \ldots ; 0,18 \times \mathrm{R}(1+\mathrm{i})^{\mathrm{D}} .
$$

Coefficient 0,18 is the derivative of the rate of profit tax $(18 \%)$.

This series in the geometrical progression with the first term $0,18 \times \mathrm{R}(1+\mathrm{i})^{\mathrm{D}}$ and set $(1+\mathrm{i})$. The sum $\mathrm{N}$ of the first terms of geometrical progression for our case is (9):

$$
\begin{aligned}
S_{N}=R 0.18(1+i)^{D} & \frac{(1+i)^{N}-1}{(1+i)-1}=R 0.18 \frac{(1+i)^{D+N}-(1+i)^{D}}{i}= \\
= & R 0.18 \frac{(1+i)^{T}-(1+i)^{D}}{i} .
\end{aligned}
$$

The value of profit, lost in recalculation for the end of the last year of operation of the fixed asset $\mathrm{T}$, appeared as the result of increase of the value of enterprise assets for each of $\mathrm{D}$ years is, correspondingly (10):

$$
\frac{0,18 \mathrm{R}}{(\mathrm{k}-1)} \times(1+\mathrm{i})^{\mathrm{D}-1} ; \frac{0,18 \mathrm{R}}{(\mathrm{k}-1)} \times(1+\mathrm{i})^{\mathrm{D}-2} ; \frac{0,18 \mathrm{R}}{(\mathrm{k}-1)}
$$

This series is also geometrical progression with the first term $0,18 \mathrm{R}$ and set $(1+\mathrm{i})$. The sum D of the first terms of geometrical progression for the last case is (11):

$$
S_{D}=\frac{0,18 R}{(k-1)} \times \frac{(1+i)^{D}-1}{(1+i)-1}=\frac{0,18 R}{(k-1)} \times \frac{(1+i)^{D}-1}{i} .
$$

Thus, the general change of the value of enterprise assets taking into account the profit, lost for $\mathrm{M}+\mathrm{D}$ years is $(12)$ : 


$$
\begin{gathered}
S_{N=D}=0,18 R \frac{(1+i)^{T}-(1+i)^{D}}{i}-\frac{0,18 R}{(k-1)} R \frac{(1+i)^{D}-1}{i}= \\
=0,18 R\left[\frac{(1+i)^{t}-(1+i)^{D}}{i}-\frac{(1+i)^{D}-1}{(k-1) i}\right]= \\
=0,18 R\left[\frac{(1+i)^{t}(k-1)-(1+i)^{D}(k-1)-(1+i)^{D}+1}{(k-1) i}\right]= \\
=0,18 R\left[\frac{(1+i)^{t}(k-1)-(1+i)^{d}(k-1+1)+1}{(k-1) i}\right]= \\
=0,18 R\left[\frac{(1+i)^{t}(k-1)-(1+i)^{D} k+1}{(k-1) i}\right] .
\end{gathered}
$$

Let's mark the general change of assents value, recalculated for the end of last year of the fixed asset operation as FV, so (13):

$$
F V n p=0,18 R \frac{(1+i)^{\mathrm{T}}(\mathrm{k}-1)-(1+\mathrm{i})^{\mathrm{D}} \mathrm{k}+1}{(\mathrm{k}-1) \mathrm{i}}
$$

This formula is a separate case and can be used only in situations, when the increase (decrease) of enterprise assets value takes place one time a year. In our case the change of assets value takes place at the expense of the difference between accelerated and ordinary systems of amortization deductions that are charged monthly ( $p$ times a year). The formula (3.2.4), modernized taking into account this note is following (14):

$$
\mathrm{FVnp}=\frac{0,18 \mathrm{R}}{\mathrm{p}} \times \frac{(1+\mathrm{i})^{\mathrm{T}}(\mathrm{k}-1)-(1+\mathrm{i})^{\mathrm{D}} \mathrm{k}+1}{(\mathrm{k}-1)(\sqrt[\mathrm{p}]{1+\mathrm{i}}-1}
$$

In situation of monthly wear and tear charging $(\mathrm{p}=12)$ the formula is following $(15)$ :

$$
\mathrm{FVnp}=\frac{0,18 \mathrm{R}}{12} \times \frac{(1+\mathrm{i})^{\mathrm{T}}(\mathrm{k}-1)-(1+\mathrm{i})^{\mathrm{D}} \mathrm{k}+1}{(\mathrm{k}-1)(\sqrt[12]{1+\mathrm{i}}-1}
$$

Let's consider the mechanism of work of this scheme on the example of LTD "Paradise shelter". The accounting policy of this enterprise provides the linear method of the fixed assets wear and tear (amortization) charging. Profitability coefficient of the capital for 2015 is 15,4\%. Let's accept, that enterprise can keep the profitability coefficient value at the level $15 \%$ for the whole time of the normative operation life of the fixed assets.

1. Let's divide all labor means in circulation in groups by the normative operation life.

2. Let's determine the initial value of objects from each group.

Let's calculate the economic effect from the use of acceleration coefficient that is 2 for each group of the fixed assets, related to the active part of productive assets of enterprise. The results of calculations are presented in the Table 1. The table demonstrates that the use coefficient of accelerated amortization of the active part of fixed assets that is equal 2, would allow raise the assets value of LTD "Paradise shelter" at the expense of profit tax credit (for the end of normative operation life of the object from each group) by 66056 grivnas by the group of fixed assets with operation life 4 years; by 184271 grivnas - with operation life 5 years; by 959061 grivnas - with operation life 7 years; by 2769865 grivnas - with operation life 8 years and by 1387322 - with operation life 10 years that is percent ratio to the value of group is, respectively: $7,68 \%, 10,08 \%, 15,95 \%, 19,23 \%, 26,55 \%$. 
Table 1

Calculation of economic effect from the use of accelerated amortization of active part of fixed productive assets (acceleration coefficient $=2$ )

\begin{tabular}{|c|c|c|c|c|c|}
\hline $\begin{array}{l}\text { Operation } \\
\text { life }\end{array}$ & $\begin{array}{l}\text { Value of group } \\
\quad \text { (grivnas) }\end{array}$ & $\begin{array}{c}\text { Acceleration } \\
\text { coefficient }\end{array}$ & Value from table & $\begin{array}{c}\text { Economic effect } \\
\text { (grivnas) } \\
(\text { gr.2×gr.4) }\end{array}$ & $\begin{array}{l}\text { In percents to the cost of } \\
\text { group property }(\%) \\
(\text { gr.5 } 100 \%) / g r .2)\end{array}$ \\
\hline 1 & 2 & 3 & 4 & 5 & 6 \\
\hline 4 & 860278 & 2 & 0,076785 & 66056 & 7,68 \\
\hline 5 & 1827310 & 2 & 0,100843 & 184271 & 10,08 \\
\hline 7 & 6012544 & 2 & 0,15951 & 959061 & 15,95 \\
\hline 8 & 14405820 & 2 & 0,192274 & - & 19,23 \\
\hline 10 & 5226009 & 2 & 0,265465 & - & 26,55 \\
\hline
\end{tabular}

Thus, based on the principle of succession of accounting policy application, only linear method of wear and tear (amortization) charging can be used for the fixed assets, introduced in operation in previous periods. The potential economic effect that can be received by enterprise under condition of change of accounting policy as to the method or wear and tear charging of the fixed assets can be calculated on the base of percent ratio, planned cost of the fixed assets, introduced in operation in each group, planned coefficients of capital profitability and acceleration.

\section{Discussion of results}

The important role in formation of competitive potential of the national economy belongs to the tax policy that creates stimuli for the rise of the national production and labor effectiveness, formation of economic environment, favorable for the development of competitive advantages of national economy. Despite the fact that in theory the taxes must not manage the whole enterprise activity and essentially change the business philosophy, in practice they are the powerful instrument of economic regulation that fully intervenes in the sphere of strategic decisions, forcing the leaders to change the tactics of enterprise activity cardinally.

The aim of leaders in most cases is the getting of maximal profit. At the same time the strivings to receive the most benefic is the very essence of entrepreneurial activity not depending on means of attaining this aim - widening of business (search for the new target markets, increase of sales - extensive way) or increase of its effectiveness (growth of labor productivity, reduction of the number of workers, optimization of tax payments - intensive way). From our point of view, the percent ratio of the value of economic effect to the value of each group of fixed assets by operation life has the significant practical importance, because the aforesaid calculation demonstrates the sum of profit, lost before the end of service life of each group of operation life. The offered algorithm of calculation of economic effect from the use of accelerated amortization at formation of accounting policy at enterprise would help its leaders to choose the necessary levers of tax planning.

\section{Conclusions}

Elaboration of the tax planning strategy is a "red line" in the general strategy of enterprise development. Tax planning as subsystem of financial management at correct organization in the conditions of tax legislation can provide optimization of profit, aimed at the rise of competitiveness of both separate enterprise and state in whole. Under conditions of globalization of the national economies of world countries, instability and unpredictability of changes, elaboration of development strategy and tax strategy in their harmonic combination would give state and enterprises the possibility to realize the moderate, fair and effective tax policy that, it its turn, is a necessary condition of effective economy and stable economic development.

The analysis of influence of accounting policy in the part of fixed assets on tax commitment allows make a conclusion that the accounting policy as the instrument of tax planning is a powerful reserve of effective enterprise activity. 
As the result of researches:

1. The role and features of tax planning organization at enterprises for their effective development in Ukraine were revealed.

2. The elements of accounting policy that influence or potentially can influence the tax commitments were considered on the example of accounting of the fixed assets at the study of questions, connected with increase of tax value at the expense of using the mechanism of accelerated amortization.

3. The algorithm of calculation of economic effect as the result of using mechanism of accelerated amortization of the active part of fixed assets on the base of value of money was offered, and the mechanism of the work of this scheme was considered on the example of practical materials of LTD "Paradise shelter".

\section{References}

[1] Smit, A. (2007). Issledovanie o prirode i prichinah bogatstva narodov. Moscow: eksmo, 960.

[2] Celigmen, B. (1976). Cil'nye mira cego: biznec i biznecmeny v amerikanckoj ictorii. Moscow: Progres, 308.

[3] Mal'tus, T., Kejns, D., Larin, Ju. (1993). Antologija jekonomicheskoj klassiki. Moscow: ekonov Kljuch, 475.

[4] Fridman, Dzh., Ordujej, N. (1997). Analiz i ocenka prinocjashhej dohod nedvizhimocti. Moscow: Delo, 480.

[5] Samujel'son, P., Nordhaus, V. (2006). Economics. Moscow: «Vil'jams», 1360. Delo, 627.

[6] Blaug, M. (1994). Teorija blagosostojanija Pigu. Economic Theory in Retrospect. Moscow:

[7] Klark, Dzh. B. (1934). Raspredelenie bogatstva. Moscow: GIZ, Gosudarstvennoe social'noekonshhmicheskoe. Izdatel'stvo: Leningradskoe otdelenienie, 302.

[8] Sismond de-Sismondi, Zh. (1897). Novye nachala politicheskoj ekonomii. Moscow, 292.

[9] Ozerov, I. H. (1908). Osnovy finansovoj nauki. Moscow: Tipografija I. D. Vytina, 530.

[10] Ivanov, Yu. (2005). Podatkove planuvannya v systemi menedzhmentu. Buhgalteriya, 9, 7-10.

[11] Babanin, V. A. (2004). Analiz mezhdunarodnogo opyta vedenija i regulirovanija offshornogo biznesa. Finansovyj menedzhment, 1, 94-100.

[12] Suprunenko, S. A. (2009). Podatkove planuvannya na pidpryyemstvah malogo biznesu. Aktualni problemy ekonomiky, 4, 135-144.

[13] Martynenko, V. L. (2006). Metodyka realizaciyi podatkovogo planuvannya na pidpryyemstvah promyslovosti. Formuvannya rynkovyh vidnosyn v Ukrayini, 1, 69-75.

[14] Zagorodnij, A. G. Yelisyeyev, A. V. (2003). Podatky ta podatkove planuvannya pidpryyemnyczkoyi diyalnosti. Lviv: Cent Biznes-Servisu, 152.

[15] Semenova, M. V. (1998). Vlijanie uchetnoj politiki na nalogovye objazatel'stva organizacii. Buhgalterskij uchet, 12, 10-17.

[16] Titov, V. V. (2011). Ocenka effektivnosti realizacii innovacionnogo potenciala predprijatija na osnove prirosta ego rynochnoj stoimosti. Region: ekonomika i sociologija, 4, 230-241. 